\title{
80 歳以上の高齢者胃癌手術と精神障害
}

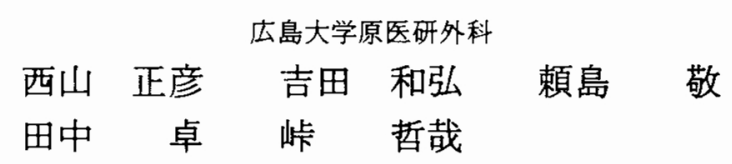

80 藏以上の高齢者胃癌手術症例52例について合併症，とくに精神障害との関連を検討した。精神障 害を含む術後合併症の発生率は術式と密接に関連しており, 幽門側胃互全摘：31\%(11/35), 胃全摘： $67 \%(8 / 12)$, 下部食道胃喷門側亜全摘：100\%（3/3），下部食道胃全摘および食道拔去胃全摘：100\% (1/1) となった。せん妄は術後最も発生頻度の高い合併症であった $(14 / 52: 27 \%)$. その発症率と平 均発現期間は，幽門側胃垔全摘：32\%(8/25)，4.5日，胃全摘：43\%(3/7)，7.0日，下部食道胃噴門 側亚全摘：100\%(3/3)，10.0日であった。また胃幽門側亜全摘術後には老年期知呆の改善が認められ たが，胃全摘術後には西村式評価で39.9から33.0（p<0.05，t 検定）と日常生活動作の低下が認めら れた. 器質的, 精神的障害両面への影響からみると, 幽門側亜全摘術では良好な経過が期待できるが, それ以上の侵襲を有する手術では周到な周術期管理が必要と考えられた。

Key words : gastric cancer in patients 80 years of age and older, postoperative complication after gastrectomy in patients 80 years of age and older, deterioration in mental status after gastrectomy in patients 80 years of age and older

はじめに

高龄化社会の到来と, 麻醉を含む周術期管理の進歩, 手術の安全性の向上とが相まって年々高龄者手術件数 が増加している。こうした高柃者外科の普遍化のなか で手術の適応と合併症について数多くの検討が行われ ている ${ }^{1) ~}$. しかしながら, その対象は心身ともに状態 の良い症例に偏る傾向があり,さらには quality of life （QOL）の概念を組み入れた手術適応の検討も端緒に ついたばかりで, 少なからぬ問題点が残されている. とくに, 精神障害に関しては周術期管理の面からも, 退院後の日常生活の面からす重要な因子であるにも関 わらず十分な検討がなされてきたとはいいがた (、4)5).

ここでは，その老人性精神障害に重点をおき，80歳 以上の高龄者胃癌症例に打ける手術について検討を 行った.

対象および方法

\section{1. 対象}

1974年 4 月より1990年10月までの期間に広島大学原 医研外科で切除された 80 歳以上の胃癌症例 52 例を対象

<1992年 3 月11日受理>別刷請求先：西山 正彦 干734 広島市南区霞 $1-2-3$ 広島大学原爆放射 能医学研究所外科
とした. 最高年龄93歳, 平均84.0歳, 男女比はほぼ 2 : 1であった (Table 1). 早期癌15例 (29\%), 進行癌 37 例 $(71 \%)$ と進行癌優位であった。胃癌に関する記載 は胃癌取扱い規約6゙によった。

\section{2. 術前合併病変}

対象症例に随伴する疾患, 機能低下, 障害 (加齢, 既往疾患によるものも含めて）を術前合併病変として 評価した。 その基準は，1）循環系：心電図異常, 高血 王, 狭心症, 心筋梗塞の既往, 2) 腎: BUN $>25 \mathrm{mg} / \mathrm{dl}$, $\mathrm{SCr}>1.5 \mathrm{mg} / \mathrm{dl}, \mathrm{CCr}<50 \mathrm{ml} / \mathrm{min}, 3)$ 呼吸器: \% $\left.\mathrm{VC}<80 \%, \mathrm{FEV} 1.0 \%<70 \%, \mathrm{PaO}_{2}<70 \mathrm{mmHg}, 4\right)$ 脳: 脳血管障害の既往, 5) 肝: GOT $>100 \mathrm{IU} / l$, $\mathrm{GPT}>100 \mathrm{IU} / l, \mathrm{~TB}>1.5 \mathrm{mg} / \mathrm{dl}$ とした.

3. 術後合併症

Table 1 Gastric cancer patients 80 years of age and older undergoing surgery

\begin{tabular}{c|c|c|c}
\hline Age & Male & Female & Total \\
\hline $80-85$ & $31^{*}$ & 16 & $47(90 \%)$ \\
$86-90$ & 3 & 1 & $4(8 \%)$ \\
$\geqq 91$ & 0 & 1 & $1(2 \%)$ \\
\hline Total & $34(65 \%)$ & $18(35 \%)$ & $52(100 \%)$ \\
\hline
\end{tabular}

*Number of patients 
手術による侵襲をみる目的で，本検討に执いては， 術後合併症のなかに術前の随伴障害が増悪したものも 含めて統計を行った。

\section{4. 精神障害評価}

$\mathrm{N}$ (西村) 式老年者用精神状態評価尺度 (Nishimura' s scale for rating of mental states of the elderly : 以 下 NM スケール) およびN（西村）式老年者用日常動 作能力評価尺度 (Nishimura's scale for rating of activities of daily living of the elderly: 以下 $\mathrm{N}$ $\mathrm{ADL})^{7) 8}$ を用い, 医師, 看護婦の記載のみからレトロス ペクティブに患者の状態を点数化した。 また痴呆の程 度は NM スケールによる評価合計点により， 0 ス 16 点: 重度痴呆, $17 \sim 30$ 点: 中等度痴呆, $31 \sim 42$ 点：軽 度痴呆，43〜47点：境界，48〜50点：正常，とした。 評価は入院時, 退院時におこなった。スコアの有意差 検定は $\mathrm{t}$ 検定にて行った。

術後せん妄の診断はアメリカ精神医学会編“精神障 害の診断・統計マニュアル第 3 版改訂版 (DMS-III-R)” の基準によった . せん妄状態では痴呆の診断はつけ られず, 術後退院前までの精神障害は, 同基準により 1 日の経過を伴って変動しやすい臨床像を示した場合 をせん妄とし，ほぼ一定した臨床像を示した場合は痴 呆の評価対象として区別した。

\section{結 果}

1. 術前合併病変

対象症例52例のらち48例 (88\%) は術前に，循環，

腎, 呼吸器系を中心としてなんらかの合併病変を有し ていたまた大半の症例が複数の機能障害あるいは疾 患を有していた。その中で高齢者精神障害（老年期痴 呆）は14例 $(27 \%)$ に認められ，その有病率は循環系 $(24 / 52 ： 46 \%)$, 腎 $(18 / 52: 35 \%)$, 呼吸器合併病变 $(16)$ $52: 31 \%$ に につぐ高率であった（Table 2).

Table 2 Preoperative physical status

\begin{tabular}{lc}
\hline & Number of patients \\
\hline $\begin{array}{l}\text { Previous cardiac disease } \\
\text { (Prior myocardial infarction, ECG }\end{array}$ & $24(46 \%)$ \\
abnormality, hypertention or angina) & \\
Renal dysfunction & $18(35 \%)$ \\
Pulmonary dysfunction & $16(31 \%)$ \\
Deterioration of mental status & $14(27 \%)$ \\
Previous CNS disease & $5(10 \%)$ \\
Liver dysfunction & $4(8 \%)$ \\
Diabetes melitus & $4(8 \%)$ \\
Healthy & $6(12 \%)$ \\
\hline
\end{tabular}

\section{2. 術後合併症}

術前有合併病変率が88\%であったにもかかわらず， 術後合併症発生率（新たな発症执よび術前随伴障害の 増悪）は24/52 (46\%) と低率であった。これらすべて の合併症は比較的早期に改善され退院可能となった。 術死は食道抜去胃全摘症例 1 例のみであった。

術後合併症として頻度の高かったものは，せん妄： 14例 $(27 \%)$ と手術自体の合併症：11例（21\%）〔縫合 不全 9 例，腸閉塞 2 例了であった。ともにおおと 4 〜 5 人に 1 人と高率で, 術後管理に扣いて最大の注意 を必要とする合併症であった（Table 3).

3. 手術術式と合併症

術後合併症の発生と術式との関係をみてみると, 術 後合併症発現率は胃幽門側亚全摘：11/35（31\%)，胃 全摘：8/12 (67\%), 下部食道胃噴門側亜全摘：3/ $3(100 \%)$, 下部食道胃全摘：1/1（100\%)，食道报去 胃全摘：1/1（100\%）となった（Table 4).

また，根治性と術後合併症および予後との関係をみ てみると, リンパ節郭清の程度と術後合併症との間に は一定の関係は認められず， $\mathrm{R}_{1}$ 症例が $63 \%(10 / 16)$ と

Table 3 Postoperative complication

\begin{tabular}{lc}
\hline & Number of cases \\
\hline Delirium & $14(27 \%)$ \\
Leakage $\quad 9(17 \%)$ \\
$\quad$ Major $\quad 2$ \\
$\quad$ Minor & 7 \\
Liver dysfunction & $6(12 \%)$ \\
Pulmonary complication & $6(12 \%)$ \\
(pneumonia, atelectasis) & \\
Intestinal obstruction & $2(4 \%)$ \\
Renal failure & $2(4 \%)$ \\
Cardiac complication & $2(4 \%)$ \\
(arrhythmia, coronary) & \\
None & $28(54 \%)$ \\
\hline
\end{tabular}

Table 4 Surgery and postoperative complication

\begin{tabular}{lc}
\hline Surgical procedure & Incidence of complication (\%) \\
\hline Subtotal gastrectomy & $11 / 35(31)$ \\
Total gastrectomy & $8 / 12(67)$ \\
Resection of the lower esophagus & $3 / 3(100)$ \\
$\quad$ and cardia & $1 / 1(100)$ \\
Resection of the lower esophagus & \\
$\quad$ and total gastrectomy & $1 / 1(100)$ \\
Transhiatal esophagectomy & \\
$\quad$ and total gastrectomy &
\end{tabular}


Table 5 Degree of lymph node dissection and postoperative complication

\begin{tabular}{cc}
\hline $\mathrm{R}$-number* & Incidence of complication (\%) \\
\hline $\mathrm{R}_{0}$ & $1 / 4(25)$ \\
$\mathrm{R}_{1}$ & $10 / 16(63)$ \\
$\mathrm{R}_{2}$ & $13 / 32(46)$ \\
\hline
\end{tabular}

*Degree of lymph node dissection defined by the general rules for the gastric cancer study

Fig. 1 Survival of gastric cancer patients 80 years of age and older undergoing surgery. Survival rate of patients who underwent curative operation $(O)$ was significantly higher than that of patients who underwent non-curative operation (-) ( $<<0.01$, Kaplan-Meier method).

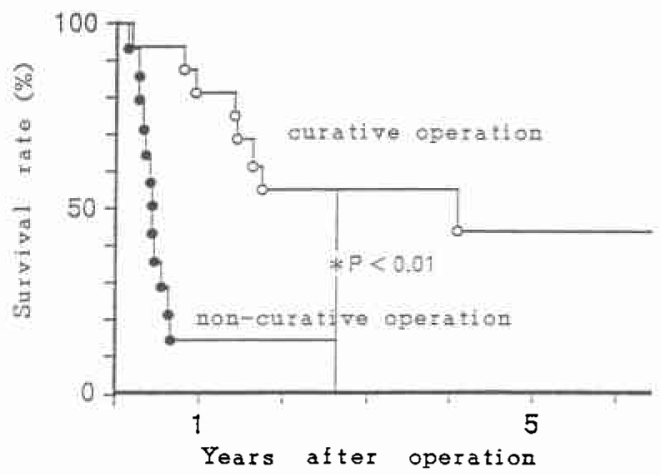

最も術後合併症発生頻度が高く, $\mathrm{R}_{2}$ 症例の同発生率は 13/32(46\%)であった(Table 5). Kaplan-Meier 法 ${ }^{10}$ にて治癋, 非治癒切除群の術後生存率を求めると, 治 瘾切除群の生存率は有意に高い結果となった（Fig. 1).

\section{4. 精神障害と手術}

術前括よび退院前に精神障害の評価を行いえた症例 は35症例であった。術後 ICU 入室, レスピレーターに よる 5 日以上の呼吸管理を必要とした症例は術後せん 妄などの評価が不可能なため対象外とした。

1) 術後せん妄

術後せん妄の症状のなかで最も頻度の高かったもの は，ドレーン，点滴などカテーテル類の自己抜去（8 例）であった。このために術後管理の上で重大な支障 を来した症例も経験された，伍かの主な症状は，不穏 状態 ( 7 例), 妄想・幻覚 ( 6 例), 大小便の不潔行為 ( 6 例), 乱暴・攻撃的行為 ( 4 例), ベッドからの起き 上がク・降下（4 例)，徘徊（2 例）であった。
Table 6 Surgery and postoperative delirium

\begin{tabular}{l|c|c}
\hline \multirow{2}{*}{} & \multicolumn{2}{|c}{ Postoperative delirtum } \\
\cline { 2 - 3 } & Incidence (\%) & Duration (day) \\
\hline Subtotal gastrectomy & $8 / 25(32)$ & $4.5^{*}$ \\
Total gastrectomy & $3 / 7(43)$ & 7.0 \\
Resection of the lower esophagus & $3 / 3(100)$ & 10.0 \\
$\quad$ & & \\
\hline
\end{tabular}

*Numbers present the mean value.

Table 7 Surgery and deterioration of mental status

\begin{tabular}{l|l|l|l|l}
\hline \multirow{2}{*}{ Surgical procedure } & \multicolumn{4}{|c}{ Mental status } \\
\cline { 2 - 5 } & NM-scale*1 & \multicolumn{2}{c}{ N-ADL } \\
\cline { 2 - 5 } & Pre $^{* 2}$ & Post & Pre & Post \\
\hline Subtotal gastrectomy & $37.4 * 3$ & 36.7 & 38.4 & 38.5 \\
Total gastrectomy & 42.0 & 41.6 & 39.9 & 33.0 \\
Resection of the lower esophagus & 45.3 & 46.7 & 34.3 & 31.7 \\
and cardia & & & \\
\hline -1NM-scale, Nishimura's scale for rating of mental status of the \\
elderly; N-ADL, Nishimura's scale for rating of activites of \\
daily living of the elderly \\
*2Pre, preoperative estimation; Post, postoperative estimation \\
*3Numbers present the mean score
\end{tabular}

せん妄の発症頻度抢よび平均発現期間と手術術式と の関係をみてみると，胃幽門側亚全摘：5/11 (45\%), 4.5 日，胃全摘： $1 / 3(33 \%), 7.0$ 日，下部食道胃噴門 側严全摘：3/3 (100\%)，10.0日となった（Table 6).

2) 手術と精神障害

西村式評価により対象症例35例の精神状態，日常生 活動作の術前と退院前の変化を検討した (Table 7). スコアの平均値でみると, 精神状態評価に関しては胃 幽門側亜全摘（術前37.4，退院前36.7), 胃全摘(術前 42.0 , 退院前41.6), 下部食道胃噴門側亜全摘（術前 45.3 , 退院前46.7）ともに変化は認められなかった。 日常生活動作に関しては, 胃全摘症例では平均スコア が術前39.9から退院前33.0（n=7） と有意に低下した $(\mathrm{p}<0.05, \mathrm{t}$ 検定 $)$.

しかしながら，術前に老年期初呆と判定された症例 のみでみると，胃幽門側严全摘術後には改善が認めら れた. 術前には正常が 7 例, 境界 7 例, 知呆11例であっ たが，退院前には正常 9 例，境界 6 例，痴呆10例となっ た，退院前に痴呆と判定された症例でも，軽度症例が 2 例から 5 例と増加し, 重度症例は 4 例から 3 例と减 少した，胃全摘，下部食道胃噴門側覀全摘症例ではほ とんど変化が認められなかった（Table 8). 
Table 8 Surgery and senile dementia

\begin{tabular}{c|c|c|c|c|c}
\hline \multirow{2}{*}{ Surgical procedure } & \multicolumn{4}{|c}{ Deterioration of mental status*1 } \\
\cline { 2 - 6 } & Normal & Border & \multicolumn{3}{|c}{ Dementia } \\
\cline { 4 - 6 } & & & slight & moderate & severe \\
\hline Subtotal gastrectomy & $7^{* 3}$ & 7 & 2 & 5 & 4 \\
Pre*2 & 9 & 6 & 5 & 2 & 3 \\
Post & 2 & 2 & 0 & 1 & 2 \\
Total gastrectomy & 2 & 2 & 0 & 1 & 2 \\
Pre & & & & & \\
Post & 0 & 3 & 0 & 0 & 0 \\
Resection of the lower & 1 & 2 & 0 & 0 & 0 \\
esophagus and cardia & & & & & \\
Pre & & & & & \\
Post &
\end{tabular}

${ }^{* 1}$ Mental status is estimated by Nishimura's scale for rating of mental status of the elderly

${ }^{* 2}$ Pre, preoperative estimation; Post, postoperative estimation

${ }^{*}$ Number of patients

\section{3）術後合併症之精神障害}

全症例に抢ける精神状態，日常生活動作スコアの変 化と器質的術後合併症の有無との関連性は認められな かった.

各器質的合併症別に精神障害に及ぼす影響をみてみ ると,るっとも影響の大きかったのは腎合併症で, 精 神状態，日常生活動作ともに低下した。手術自体の合 併症, 呼吸器合併症では日常生活動作のみ低下を認 めた。一方, 循環器系合併症を引き起こした症例では 精神状態，日常生活動作ともに改善する結果となった (Table 9).

\section{考察}

高秢者胃癌症例に対する手術の適応および術式の選 択に際し，危険度と予後とのバランスだけではなく， 患者のQOL 考虑した外科的判断が強く要求されて いる. 本検討では術後合併症の発生頻度, 予後に加党, 老人性痴呆を含めた手術による精神障害, 術後の日常 生活への影響の解析を試みた。そ結果, 胃幽門側亜 全摘術にて根治性の得られた症例では良好な経過が期 待できるが，それ以上の侵襲を有すると考えられる術 式を選択した場合には周到な周術期および退院後の管 理が必要であること,が示唆された。

80歳以上の高齢者手術の術後合併症発生率は, ほか の年齢に比較し高率ではあるものの, 待機手術後の死 亡率は低く，長期生存率も期待しうることが報告され ている ${ }^{2) 11122}$. 胃癌症例のみを対象とした本検討でも， 術前合併病変の増悪を含めた術後合併症の発生率は
Table 9 Influence of postoperative complication on deterioration of mental status

\begin{tabular}{l|l|l|l|l}
\hline \multirow{2}{*}{$\begin{array}{l}\text { Postoperative } \\
\text { complication }\end{array}$} & \multicolumn{4}{|c}{ Mental status } \\
\cline { 2 - 5 } & \multicolumn{2}{|c|}{ NM-scale*1 } & \multicolumn{2}{c}{ N-ADL } \\
\cline { 2 - 5 } & Pre $^{* 2}$ & Post & Pre & Post \\
\hline Leakage & & & & \\
$\quad$ Major & $44.3^{* 3}$ & 40.3 & 45.7 & 39.7 \\
$\quad$ Minor & 45.0 & 44.5 & 44.0 & 36.5 \\
Liver dysfunction & 36.4 & 36.8 & 33.8 & 33.0 \\
Pulmonary complication & 34.3 & 32.3 & 35.0 & 18.3 \\
Intestinal obstruction & 36.5 & 36.0 & 44.0 & 37.0 \\
Renal failure & 45.5 & 21.0 & 47.5 & 21.0 \\
Cardiac complication & 15.0 & 23.0 & 9.0 & 21.0 \\
\hline
\end{tabular}

${ }^{* 1}$ NM-scale, Nishimura's scale for rating of mental status of the elderly ; N-ADL, Nishimura's scale for rating of activities of daily living of the elderly

${ }^{* 2}$ Pre, preoperative estimation; Post, postoperative estimation

${ }^{*}$ Numbers present the mean score

$46 \%$ であったが，術死は 1 例のみであった。またリ ンパ節郭清の程度と術後合併症の頻度も相関せず, 治 癒切除症例の生存率は非治癒切除症例に比較し有意に 高いものとなった， $\mathrm{R}_{0}, \mathrm{R}_{1}$ 施行症例が術前危険度の高 い症例であったことにもよるが，高齢者だといら理由 だけで根治性を安易に犠牲にすることは避けるべきと 考兄られた，対象症例の高い術前有合併症率（88\%） を考慮すると，この成績は全身状態・予備能力による 症例選択の結果ではないと考光られ，適切な周術期管 
理により手術の幅が広げられらることを示していると 考穴られた。

しかしながら，手術侵襲の術後合併症発症に及ぼす 影響は決して少ないるのではなかった。術式別の術後 合併症発生頻度でみると, 胃幽門側亜全摘では11/ 35 (31\%) であったが，胃全摘：8/12(67\%)，下部食 道胃噴門側严全摘：3/3(100\%)，下部食道胃全摘およ び食道拔去胃全摘：1/1（100\%）となり，胃幽門側亚 全摘術と胃全摘術との間に明らかな差が認められた。 したがって現段階では，手術の安全性は向上しつつあ るものの, 根治度を含めた術式の選択には患者の全身 状態と手術侵襲とのバランスの慎重な配慮が必要と考 えられた。

手術と患者のQOL との関係をみるため手段として 行った患者精神状態，日常生活活動の点数化による検 討でも，手術侵襲の影響の大きさが確認された。胃幽 門側要全摘術施行症例では術前の精神状態, 日常生活 動作の評価が比較的低かったにもかかわらず，退院前 の平均スコアの低下は認められなかった。また，術前 に比較し，老人性痴呆の改善も認められた。しかしな がら, 胃全摘術施行症例では術後の日常生活動作は有 意に低下し, 痴呆症例の改善傾向も認められなかった。 胃全摘術施行症例の退院前の一般的像をスコアから導 きだすと，伝い歩きをし，話の大半は理解できるもの の時に失禁し，入浴・食事には介護を要する，となっ た. 退院後の精神状態, 日常生活動作の点数化が十分 でないため結果を明示することはできないが，胃亜全 摘術以外の手術例では退院後に介護を必要としている 症例が大半であった。

これらの結果は，術式によっては“寝たきり”ある いは“ぼけ”が招来されることを示したものと考劣ら れ, 手術適応, 術式の決定には安全性, 予後だけでは なく, 術後の精神状態, 日常活動能力に対する十分な 考察が必要とされよう，痴呆の成因として日常活動の 制限が大きくかかわっていると考光られており，日常 生活動作評価の低下をきたすと考えられる術式を選択 せざるをえない場合には可能な限り侵襲を軽減する努 力が必要之考学られた。

また，手術侵襲の程度は，術後一過性に出現する精 神障害（術後せん妄）とも直接的な関連性を有してい た。 せん妄は $27 \%(14 / 52)$ と術後最も発生頻度の高い 合併症であったが，その発症率と発現期間には術式に より差が認められた。胃幽門側亜全摘術施行症例は最 も発生頻度が低く発現期間も短かったが, 胃全摘, 下
部食道胃噴門側覀全摘では発症頻度も高くなり，せん 妄発現も長期のものとなった。術前の精神障害の有無 とせん妄の発症とは無関係であったことから80歳以上 の高龄者はすべて精神障害準備状態にあると考えるべ きで，離床可能となるまでの期間が最も重要であると 思われた。疼痛除去とともに，回復に長期間を有する 術後合併症の予防に留意が必要であろう。事実, 腎, 呼吸器, 手術自体による合併症を引き起こした症例で は回復後も日常生活動作スコアの低下が認められ，入 院中の精神障害のみではなく退院後の日常生活制限,

精神障害の増悪を示唆する結果となった。

高龄者手術の場合, “余命”之の関係から緊急手術を 除き延命の事実を把握することがきわめて難しい，そ の意味からもQOLの手術適応・術式決定に扮ける比 重は一般症例に比べ，大きなるのであるとい兄よう。 周術期管理の進歩, 高齢者の健康状態の改善が著しい 今日, 手術適応の拡大化は想像に難くない，正しい手 術適応とは安全性の面のみではなく, 術後の日常生活 の向上を保証するべきものでなければならない，その ためには，質をも含めた信頼でさる予後調查と，精神 障害の管理，予防に関する具体的な対応指針が必要で ある，今後，さらに検討を続け，高齢者胃癌症例に対 する明確な手術適応の決定と管理の留意点を示したい と考兊ている。

本論文の要旨は第38回日本消化器外科学会総会において 発表した。

1）林 四郎：高齢者に対する手術と術後のケア。日 医師会誌 $101 ： 636-638,1990$

2）元木良一,井上 化, 寺島信也：合併症を百高齢 者の手術適応々侵襲範围。消外 $14: 37-43,1991$

3）川原田嘉文, 古峰修時: 術前検查成績と手術危険 度. 外科治療 $50: 63-71,1984$

4）平沢秀人：老人の術後せんも5の臨床的研究：せ んも5の発現機序について。精神誌 92 : $391-410,1990$

5）山城守也：高龄者の術後精神障害とその対策。消 外 $14: 65-71,1991$

6）胃癌研究会編：胃癌取扱い規約. 改訂 11 版. 金原 出版, 東京, 1985

7）小林敏子, 播口之朗, 西村 健仿か: 行動観察に上 る知呆患者の精神状態評価尺度 (NM スケール)扔 よび日常生活動作能力評価尺度 (N-ADL)の作成. 臨精医 $17: 1953-1959,1988$

8）西村 健, 福永知子, 小林敏子：知的機能検查の使 い方とその評価。西村 武。老年期痴呆 3 : 86-92, 1989 
9）高橋三郎訳 : DSM-III-R 精神障害の診断. 統計 $=$ マアル, 第 3 版. 医学書院, 東京, 1988, p96-99

10) Kaplan EL, Meier P: Nonparametric estimation for incomplete observations. J Am Stat Assoc 53 : 457-481, 1961
11）市川英幸, 安名 主, 林 四郎：80 歳以上の高齢 者胃癌の臨床病理学的検討. Geriat Med 28： $547-551,1990$

12）林 四郎：周術期のケア。南山堂, 東京, 1990

\section{Surgery and Deterioration of Mental Status in Gastric Cancer Patient 80 Years of Age and Older}

Masahiko Nishiyama, Kazuhiro Yoshida, Takashi Yorishima, Takashi Tanaka and Tetsuya Toge Department of Surgery, Research Institute for Nuclear Medicine and Biology, Hiroshima University

The outcome of surgery in 52 gastric cancer patients 80 years of age and older was investigated, especially from the viewpoint of deterioration in mental status. The occurrence of postoperative complications including deterioration in mental status was closely related to the surgical procedure. The incidence was $31 \%(11 / 35)$ in subtotal gastrectomy, $67 \%(8 / 12)$ in total gastrectomy, $100 \%(3 / 3)$ in resection of lower esophagus and cardia, $100 \%$ $(1 / 1)$ in resection of lower esophagus and total gastrectomy, and $100 \%(1 / 1)$ in transhiatal esophagectomy and total gastrectomy. Delirium, which developed in 14 of 52 patients $(27 \%)$, was the most common postoperative complication. The incidence and average period of occurrence were $32 \%(8 / 25)$ and 4.5 days in subtotal gastrectomy, $43 \%(3 / 7)$ and 7.0 days in total gastrectomy, and $100 \%(3 / 3)$ and 10.0 days in resection of lower esophagus and cardia. Activity score of daily living estimated by Nishimura's scale in patients with total gastrectomy decreased from 39.9 to 33.0 ( $p<0.05$, student $t$-test), although improvement of senile dementia was observed in the patients who had undergone subtotal gastrectomy. We conclude that the outcome of subtotal gastrectomy is favorable considering the postoperative complications and mental changes in patients 80 years of age and older. Nevertheless, to prevent the major morbidity associated with surgery, scrupulous care is needed for the patients who require more aggressive surgical procedure.

Reprint requests: Masahiko Nishiyama Department of Surgery, Research Institute for Nuclear Medicine and Biology, Hiroshima University 1-2-3 Kasumi, Minami-ku, Hiroshima, 734 JAPAN 